\title{
THE GRAZING RATE OF PLANKTONIC COPEPODS
}

\author{
By D. T. Gauld, B.Sc., Ph.D. \\ Department of Zoology, University of Edinburgh, and the Marine Station, Millport
}

\author{
(Text-figs. I-4)
}

\section{INTRODUCTION}

The source of the food of planktonic animals has been frequently discussed since, on the basis of his calculations of food requirements, Pütter proposed in 1907 that the particulate food available to them was quite inadequate for their needs and that they must therefore derive the greater part of their nourishment from organic substances dissolved in the water. Critical study of Pütter's experiments showed that they were unreliable, and his calculations were made generally invalid by the publication in I908-II of Lohmann's work on the nanoplankton in sea water. In these studies Lohmann drew attention to the existence in the sea of enormous numbers of organisms, mainly unicellular algae, from I to $25 \mu$ in diameter and length, and too small to be captured by plankton nets. He was also able to show that the Appendicularia obtained their food from these minute organisms and were able to filter in an hour a volume of water many thousand times their own size. Pütter tried to show that even here the amount of plankton filtered was inadequate. Krogh (I93I) pointed out that Pütter based his calculations on the numbers of organisms found in the filters, and overlooked the fact that the contents would be emptied into the gut at regular intervals, and he commented (p. 4I5): 'It must however be admitted that Lohmann on his side did not prove the sufficiency of the nanoplankton food for the Appendicularia.'

Pütter (1909, I925) included Copepoda among the animals which would be unable to obtain enough particulate food from sea water. As Krogh (I93I) remarked, the existence in these animals, as in others, of a well-developed gut and a complex apparatus adapted to the acquisition of particulate material is itself evidence that the bulk of their food is particulate, and examination of the contents of the gut shows the presence of particulate food (Dakin, I908; Esterly, 1916; Lebour, 1922; Marshall, 1924). Even Pütter himself mentions 'eine grüne Masse' which was undoubtedly made up of nanoplankton flagellates. But no attempt was made to find out whether the copepods could obtain a sufficiently large quantity of food by collecting the minute organisms present in the water until 1936, when Fuller \& Clarke measured the filtering rate of Calanus finmarchicus. 
The amount of food which a filter-feeding animal can obtain in a given time is determined by the volume of water which it can filter in that time, the concentration of suitable food particles in the water, and the efficiency of the filtering mechanism. The filtering rate, i.e. the rate at which water is passed through the food-catching apparatus, is independent of the concentration of the food particles, but is dependent, like any other biological process, on the physical and chemical conditions of the environment and on the activity of the animal. For example, filtering may be discontinuous and in consequence the filtering rate during active feeding may be considerably greater than that indicated by measurements made over longer periods which include periods of inactivity. The efficiency of the filtering apparatus will depend on the size of the particles, being greatest for those which are neither so small that they are able to pass through the apertures of the filter, nor so large that they obstruct the filtering apparatus. It is possible, however, that, even with particles of uniform size, the efficiency of the filter may be variable, and may be under some kind of control by the animal.

The measurements of Fuller \& Clarke (1936) and those of Fuller (1937) seemed to show that the animal's power of catching particulate food was quite inadequate for its needs. Fuller \& Clarke found that Calanus, a large copepod, could sweep clear of carmine particles $4.5 \mathrm{ml}$. of water per day. At the same time they estimated that in order to supply its needs it would have to sweep clear about $72 \mathrm{ml}$. of water containing a rich natural diatom population. In 1937, estimating the food requirements on a different basis, Fuller stated that even with the maximum rates of filtering in his experiments ( $2.88 \mathrm{ml}$. per day) Calanus would have obtained, in water where it is known to thrive, less than one-tenth of the required amount of its food from particulate matter. On the other hand, Harvey (1937) reports a small number of experiments in which he found far more rapid filtering rates for Calanus, 2-4 ml. swept clear per hour with Lauderia borealis, a medium-sized diatom, and 7-IO $\mathrm{ml}$. per hr. with the larger Ditylium brightwelli.

In his measurements of filtering rates, Fuller (1937) found no correlation between the concentration of food and the filtering rate, and concluded that Calanus obtained its food by filtering particles from a stream of water passed through the setae of the posterior cephalic appendages, and made his investigation on this assumption. However, Lowndes (1935), basing his views on anatomical grounds and on the fact that crustacean remains have been reported from the gut, states (p. 702) 'It is difficult to see any justification for describing the feeding of Calanus finmarchicus as being either automatic or non-selective', and implies that the bulk of its food is obtained by seizing and chewing up larger particles, especially other crustaceans.

The experiments which are to be described below throw some light on the question of filter-feeding by copepods and of the magnitudes of the filtration rate. 


\section{ACKNOWLEDGEMENTS}

The author is indebted to Prof. J. Ritchie, of the Department of Zoology, University of Edinburgh, for his interest in the work and for his careful reading of the manuscript, and to $\mathrm{Mr} \mathrm{E}$. Ford, Director of the Marine Biological Station, Millport, for his helpful criticism during the last part of it. Some of the work was done while the author held a Jacobsson Fellowship at the Oceanographic Institute at Göteborg, and he would like to thank Prof. Hans Pettersson and the Board of the Göteborgs Sjöfartsmuseum for giving him the opportunity of doing this work. Finally, he acknowledges the assistance of the late Dr F. Gross, who supplied the cultures with which the experiment started and who gave ready help and advice throughout the work.

\section{Material AND Methods}

The experiments to be described fall into three groups; (i) those done in the Department of Zoology, Edinburgh University (Series A and D); (ii) those done in the Oceanographic Institute, Göteborg (Series B and C); and (iii) those done at the Marine Station, Millport (Series E-G). On arrival at the laboratory the copepods were sorted and transferred to cooled sterile sea water in 'breffit' jars, and at Edinburgh and Göteborg kept in a refrigerator the upper temperature limit of which was set at $10^{\circ} \mathrm{C}$. At Millport the jars in which the copepods had been placed were kept in running water to cool them. Some preliminary experiments were done with the diatom Skeletonema costatum as food. In these experiments the diatoms occasionally settled to the bottom of the dish during the experiments, especially in experiments done in darkness. In consequence these experiments had to be abandoned, and the Skeletonema culture was replaced by one of a species of Chlamydomonas. Chlamydomonas is an actively motile flagellate; its approximate dimensions are: length 9.5I3. $8 \mu$, diameter 6-8.4 $\mu$ (Raymont \& Gross, I942) and no evidence was ever seen of its settling or being unevenly distributed in any way.

For the experiments a culture of Chlamydomonas was diluted with sterile sea water, and divided among a number of beakers or large crystallizing dishes, each one receiving 100 or $\mathrm{I} 50 \mathrm{ml}$. of this experimental medium. In some of the jars one or more, according to their size, healthy active copepods were placed; others were kept as controls. The concentration of the suspension of the food organism was estimated at the beginning of the experimental period, usually about $24 \mathrm{hr}$., and again at the end. Usually at the end of one experiment the copepods were transferred into a second set of vessels and a new experiment started.

In the first two series of experiments ( $A$ and $D$ ) the concentration of the culture of the food organism was measured by its extinction of light in a 'Unicam' photometer. This method was satisfactory only if the concentration of the food organism was rather high-very much higher than likely to occur in nature. 
There was a possibility therefore that the behaviour of the copepods might be abnormal in such conditions, so that this method was later abandoned in favour of counting. In all the other experiments the concentrations were measured by counting the Chlamydomonas cells on a Fuchs-Rosenthal counting slide-four millimetre squares from each of five drops, making a total of four microlitres, were counted from each experimental vessel. The agreement between the counts of different drops and between the counts of different squares from the same drop was generally good.

If it is assumed that a copepod is a filter-feeding animal, then in an experimental vessel where the physical and chemical conditions are kept constant, the concentration of food particles in the presence of a steadily grazing copepod will decline exponentially, and at any given time it is given by the expression

$$
C_{t}=C_{0} e^{-k t},
$$

where $C_{t}$ is the concentration after time $t$, and $C_{0}$ the initial concentration.

Further if $v$ is the volume of water per animal, then $v k$ is the volume of water swept free by one animal in unit time, so that the filtering rate (F) is given by

$$
F=v k .
$$

This expression can be evaluated from (I) in the form

$$
F=v \frac{\log _{10} C_{0}-\log _{10} C_{t}}{t \log _{10} e} .
$$

The results of the experiments to be described were evaluated from this formula (3) and expressed as millilitres of water swept clear by one copepod in the period covered by the experiment, usually 18 or $24 \mathrm{hr}$.

\section{EXPERIMENTS}

A summary of the experiments and their results is given in Table I, and Figs. I-3 show the results in greater detail. In the figures, the volume swept clear is plotted against the concentration of the control cultures.

Fig. I gives the results of the experiments done with Pseudocalanus. The results of experiments with Temora and Centropages are given in Fig. 2 and those with Calanus in Fig. 3.

Of the experiments with Calanus Stage V (Series E), and Stage IV (Series F), most were done over $\mathrm{I} 8 \mathrm{hr}$., starting at about $\mathrm{I} 6.00 \mathrm{hr}$. and finishing about I0.00 hr. the following day, i.e. the experimental period included the hours of darkness. But in Series E six experiments were continued for $24 \mathrm{hr}$. and eight for only $\mathrm{I} 2 \mathrm{hr}$. The means of these two groups were respectively $82 \cdot 3 \mathrm{I}$ and $73.62 \mathrm{ml}$. swept clear, in comparison with $69.66 \mathrm{ml}$. swept clear for the 


\section{TABLE I}

\begin{tabular}{|c|c|c|c|c|c|c|c|c|}
\hline Serie & $\begin{array}{l}\text { No. of } \\
\text { experi- } \\
\text { ments } \\
\text { in } \\
\text { s series }\end{array}$ & Species & $\begin{array}{c}\text { No. of } \\
\text { copepods } \\
\text { per } \\
\text { vessel }\end{array}$ & $\begin{array}{c}\text { Volume } \\
\text { of } \\
\text { vessel } \\
\text { (ml.) }\end{array}$ & $\begin{array}{c}\text { Dura- } \\
\text { tion } \\
\text { (hr.) }\end{array}$ & $\begin{array}{c}\text { Tempera- } \\
\text { ture } \\
\left({ }^{\circ} \mathrm{C} .\right)\end{array}$ & $\begin{array}{l}\text { Mean } \\
\text { volume } \\
\text { swept } \\
\text { clear } \\
\text { per } \\
\text { copepod } \\
\text { (ml.) }\end{array}$ & $\begin{array}{c}\text { Standard } \\
\text { deviation } \\
\sigma\end{array}$ \\
\hline A & $2 I$ & Pseudocalanus minutus & I & Io & 24 & Io & $4 \cdot 28$ & $I \cdot 46$ \\
\hline B & 45 & Temora longicornis & Io & 150 & 24 & Io & $8 \cdot 38$ & $I \cdot 9 I$ \\
\hline c & 8 & Centropages hamatus & Io & 150 & 24 & Io & 12.99 & $\mathrm{I} \cdot 20$ \\
\hline D & I9 & $\begin{array}{l}\text { Calanus finmarchicus } \\
\text { stage V }\end{array}$ & I & 100 & 24 & 12.5 & $64 \cdot 36$ & II.63 \\
\hline E & 77 & $\begin{array}{l}\text { C. finmarchicus } \\
\text { stage V }\end{array}$ & I & IOO & I8 & 17 & $71 \cdot 03$ & I3.17 \\
\hline $\mathrm{F}$ & 25 & $\begin{array}{l}\text { C. finmarchicus } \\
\text { stage IV }\end{array}$ & 2 & IOO & I8 & I7 & $36 \cdot 65$ & $8 \cdot 75$ \\
\hline G & I3 & $\begin{array}{l}\text { C. finmarchicus } \\
\text { stage III }\end{array}$ & 3 & 100 & I8 & I7 & $22 \cdot 24$ & $5 \cdot 5^{8}$ \\
\hline
\end{tabular}

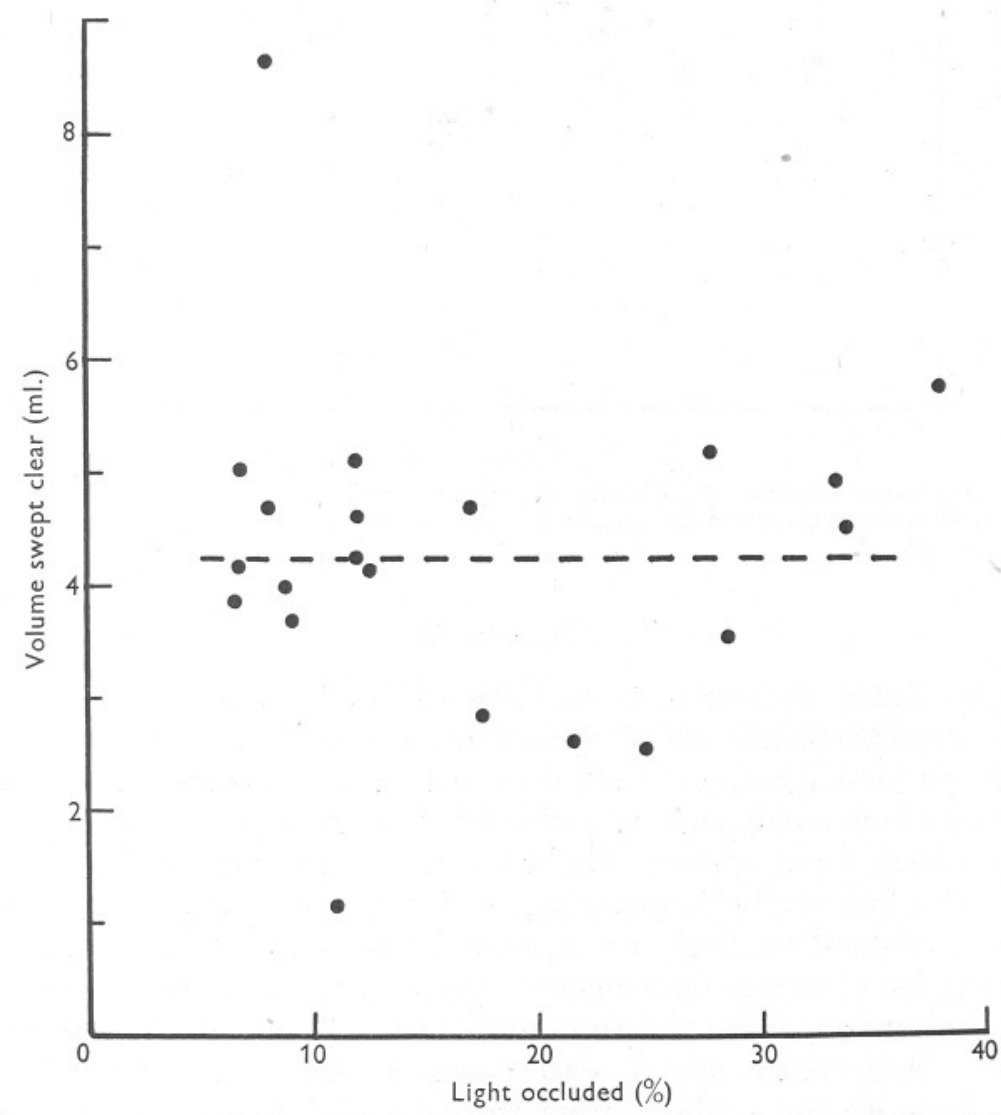

Fig. I. Pseudocalanus minutus. Volume (ml.) of culture swept clear compared with the concentration of the control culture, measured by the percentage of light occluded. 
remainder measured over $\mathrm{I} 8 \mathrm{hr}$. The difference between the volumes swept clear in $\mathrm{I} 2$ and $\mathrm{I} 8 \mathrm{hr}$. is not significant. The increased volume swept clear in $24 \mathrm{hr}$. is possibly significant, but only just so $\left(\mathrm{D} / \sigma_{m}=2 \cdot \mathrm{I}\right)$.

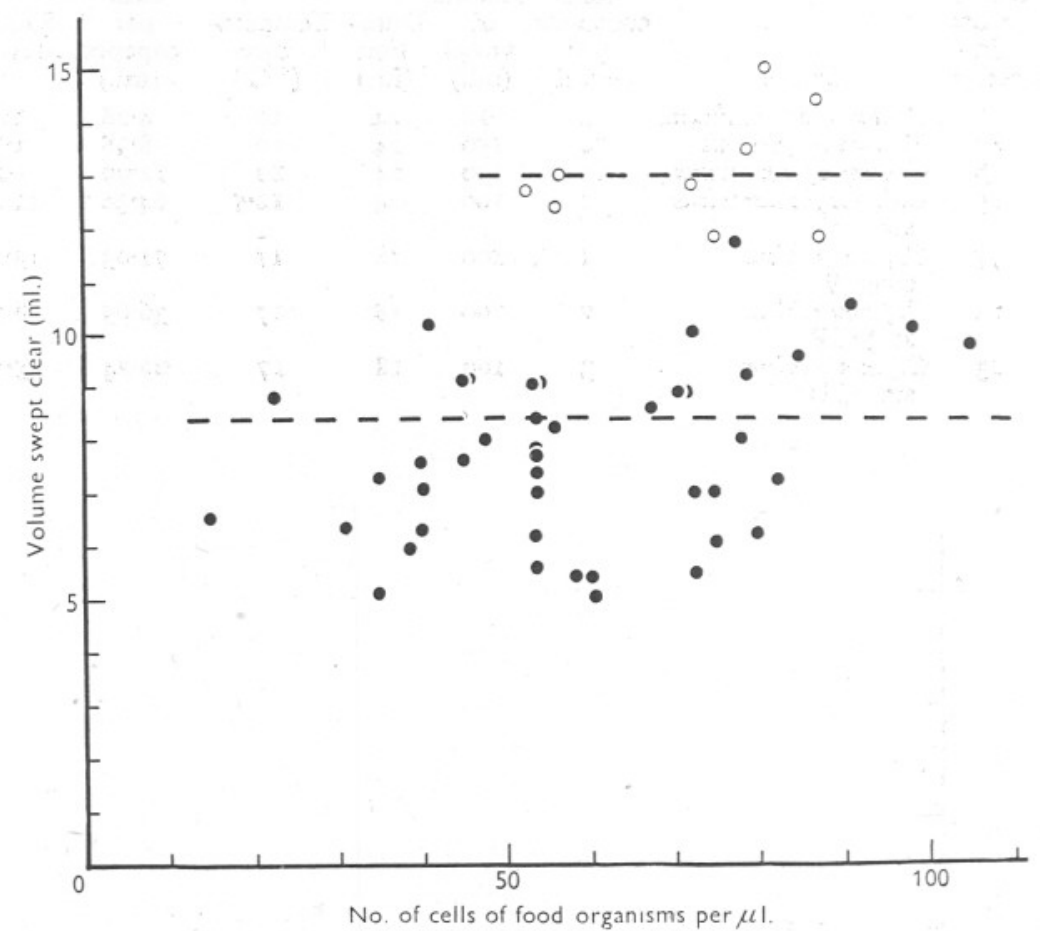

Fig. 2. Centropages hamatus (open circles) and Temora longicornis (black circles). Volume (ml.) of culture swept clear compared with the concentration of the control culture, measured as cells per $\mu \mathrm{l}$.

\section{Discussion}

It is immediately obvious from the scatter of the points in the diagrams that in these experiments the animals were acting as filter-feeders. If they had been collecting a fixed quantity of food, the scatter of the points would have shown some trend from the upper left-hand side of the figure to the lower right-hand side: no such trend appears. On the contrary, the number of Chlamydomonas cells consumed by Calanus Stage V (Series E), for example, ranges from a minimum of about 250,000 to a maximum of $2,000,000$, i.e. the largest amount consumed was eight times the smallest. On the other hand, the largest volume swept clear, Ior ml., is less than three times the smallest, $42 \mathrm{ml}$. That the volume filtered is independent of the concentration of the food particles is shown more clearly in Fig. 4 where, from the data of Series C, the difference in the concentration produced by one Temora in $24 \mathrm{hr}$. is plotted against the 
concentration of the initial cultures. Here there is a very clear trend from lower left-hand side to the upper right-hand side of the figure, and the broken line in the figure is the graph of the difference produced by a steady filtration rate of $8.38 \mathrm{ml}$. in $24 \mathrm{hr}$., the mean of the observed rates. Similar figures could be drawn for the other series of experiments. These findings are therefore in agreement with Fuller's that there is no correlation between the concentration of the food particles and the filtering rate.

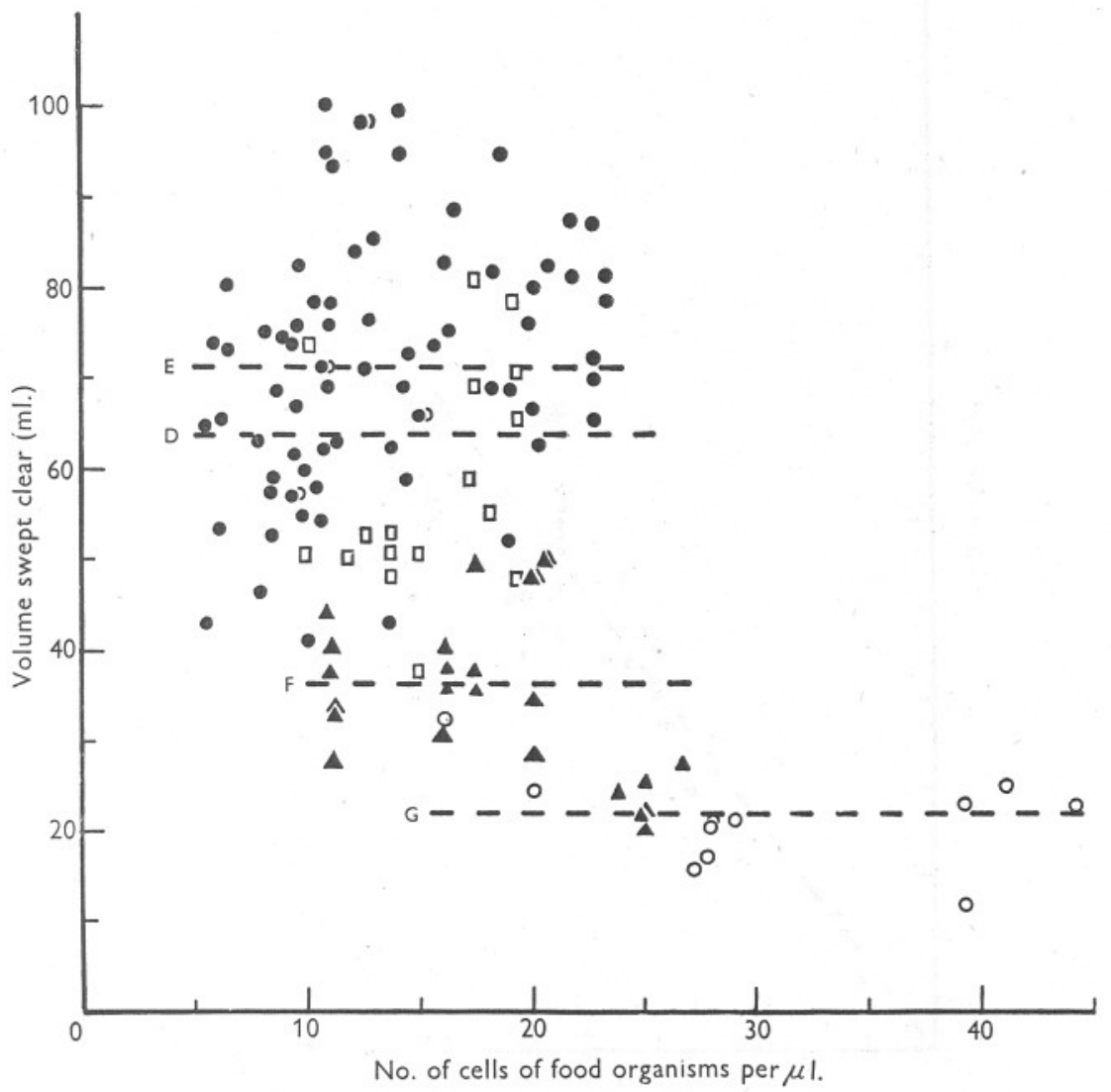

Fig. 3. Calanus finmarchicus. Volume (ml.) of cultures swept clear compared with the concentration of the control culture, measured as cells per $\mu 1$. $\square$, Series D, StageV;, , Series E, Stage V; $\boldsymbol{\Delta}$, Series F, Stage IV; O, Series G, Stage III.

It may be objected that, while these figures (like Fuller's) show that the animals collected all the food from a given volume of water, they do not prove that it was collected by filtration although they make it more likely. However, the total number of particles consumed can readily be calculated and those for Calanus Stage V have already been mentioned. If it is assumed that the copepods worked continuously for the whole period of the experiment, although 
it has been suggested that this may not be so, it is possible to calculate how many particles were collected in unit time. In the experiments with Calanus Stage V (Series E) this works out at nearly 4 per sec. from the lowest figure to over 30 per sec. from the highest. Similar collecting rates apply to the other experiments; Temora, for instance, collected particles at a rate of from $I_{2}^{\frac{1}{2}}$ to 9

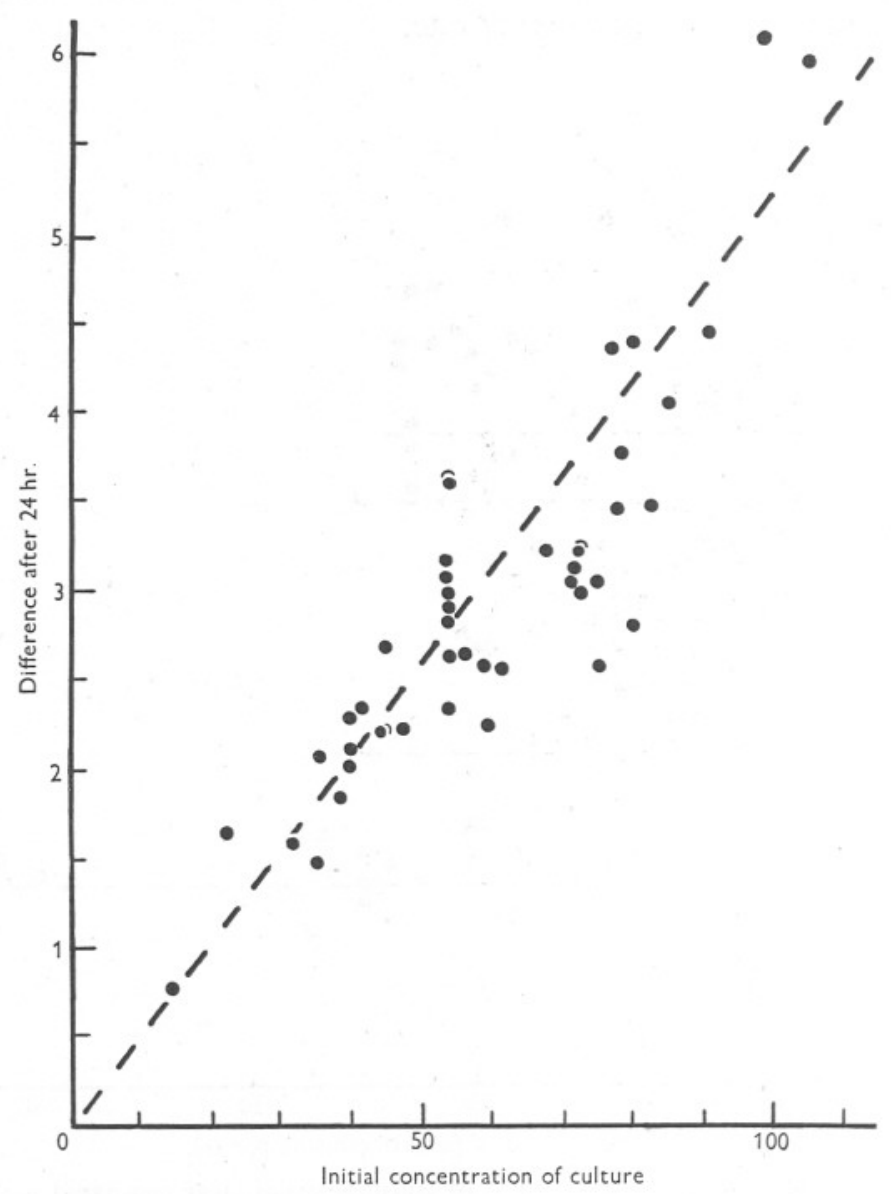

Fig. 4. Temora longicornis. Difference in the concentration of food organisms produced by one copepod in $24 \mathrm{hr}$. plotted against the concentration of the initial culture. Units are cells per $\mu \mathrm{l}$.

particles per sec. in the experiments in Series C. It is difficult to imagine any way in which the animals could collect particles so rapidly except by filtration, especially since it is probable that the copepods fed actively during a part only of the experimental period and so must have collected their food even more rapidly than the figures show. 
The magnitude of the filtering rates found here for Calanus is much greater than those found by Fuller \& Clarke (I936) and Fuller (I937). The I936 measurements were made by estimating the rate at which carmine particles were removed from the water. Some of the carmine was definitely ingested but it is possible that the bulk was rejected after it had been collected on the filtering apparatus and that the apparently low filtering rates were due to return to the water of the particles so rejected. Fuller (I937) measured the filtering rate by estimating the change in the concentration of cultures of the diatom Nitzschia closterium (Plymouth strain), and found rather smaller filtering rates than Fuller \& Clarke. A priori, Nitzschia might appear to be suitable for such measurements since Calanus has been reared on cultures of this diatom (Crawshay, I9I5), but the experiments of Harvey (I937) seem to show that for some reason it is unsuitable, since he found very low filtering rates with Nitzschia although with other diatoms, Ditylium and Lauderia, he obtained very much higher rates. One criticism may be made of Fuller's experiments. The measurements were made in vessels in which three copepods were confined in $15 \mathrm{ml}$. of water. In view of the size and activity of Calanus this seems to be a very small amount of water for each animal, and indeed it is difficult to see how volumes swept clear much larger than $5 \mathrm{ml}$. per animal could be measured in such experiments.

The measurements of Harvey (1937) are of the same order of magnitude as those recorded here for Calanus, but immediate comparison cannot be made because his experiments covered variable and rather short periods and the results are given as filtering rates per hour. If it is true that Calanus filters intermittently, results based on short periods of observation are liable to be misleading, since an experiment which covers a period of a few hours may or may not include part of a period of active filtration. Two of Harvey's experiments however covered a $24 \mathrm{hr}$. period and the volumes swept clear in these were 74 and $94 \mathrm{ml}$. per Calanus. One experiment of $48 \mathrm{hr}$. showed a total filtration of $96 \mathrm{ml}$. per copepod, and of the measurements made over periods of less than $24 \mathrm{hr}$. none exceeded $70 \mathrm{ml}$. These results therefore do not contradict the hypothesis that Calanus filters a volume of about $70 \mathrm{ml}$. per $24 \mathrm{hr}$., but that the greater part of this filtration is confined to a relatively short period.

Riley, Stommel \& Bumpus (1949) calculated the filtering rates of mixed plankton populations, and found filtering rates of 80-I Io ml. swept clear per day for each milligram (wet weight) of zooplankton. Bogorov (1934) gives the wet weight of Calanus Stage $\mathrm{V}$ as varying between 0.35 and $0.70 \mathrm{mg}$. with a mean value of $0.53 \mathrm{mg}$. From these figures the filtering rate of Calanus Stage V can be calculated, giving an overall range of from 28 to $77 \mathrm{ml}$. swept clear per day, values which agree very well with those found in the present experiments, in spite of the roundabout way in which they have been reached.

Fuller (1937) found that the diatom concentration in his experimental vessels often remained stationary for a day or more, showing that feeding was 
not a continuous process, and in some of his experiments he reported a diurnal feeding rhythm in which the diatoms were removed more rapidly at night. Such a rhythm is suggested by the observation in the present experiments that there is little difference between the amount of grazing in I2, I 8 or $24 \mathrm{hr}$., but sufficient evidence is not available to show the period, or periods, during which grazing was most active, or the causes of the rhythm.

Comparison of the filtering rates found for the different species and stages is difficult because the experiments were carried out at different temperatures. If, however, it is assumed that the relation between temperature and filtration rates is the same as that between temperature and respiratory rate, and the observed rates are all corrected for a single temperature $\left(10^{\circ} \mathrm{C}\right.$.), it can be shown that the filtering rates are approximately related to the squares of linear dimensions. (The correlation coefficient between the filtration rate and the square of the length is 0.84.) However, the range of size covered by these experiments is small and the variation in the observed values of the filtering rates rather large, so that more detailed mathematical investigation of this relation is not justified without further evidence.

In discussing Harvey's results, Fuller (1937) suggested that Calanus was better able to retain large particles on its filtering surface than small ones, and that the low filtering rates found by Harvey and himself with Nitzschia were due to the small cells of Nitzschia passing through the filter. But Harvey's observation (Exp. C, p. 98) that, in a mixed suspension of Lauderia borealis and a species of Chaetoceros, Calanus reduced the concentration of Lauderia from I3 to I.9 per ml. in $48 \mathrm{hr}$. 'without any considerable reduction in the Chaetoceros population', cannot be explained in this way. The species of Chaetoceros used in this experiment was almost certainly larger than Nitzschia closterium forma minutissima, which Harvey found to be removed in appreciable amounts, though much more slowly than Lauderia in Exp. N 90. Wilson (1946) states that this form of Nitzschia is $3-4 \mu$ in diameter and $25-35 \mu$ in length. It is impossible to be certain of the size of the Chaetoceros species used, but none of the measurements given in Lebour (1930) for any species of Chaetoceros is less than $4 \mu$ broad. In addition, Nitzschia closterium is a solitary species while the species of Chaetoceros nearly all form chains and the spines characteristic of the latter genus might increase the effective diameter of a chain of cells, possibly to five times that of the cells. Riley et al. (1949) suggested that the result of Harvey's experiment was due to the rejection by Calanus of Chaetoceros, 'which in chains would presumably be larger than Ditylium' (p. 64), and implied that Chaetoceros in chains was too large to be eaten by Calanus. This is not so since Calanus is known to feed on Chaetoceros (Marshall, I924; Raymont \& Gross, 1942). That chains of Chaetoceros cells may be larger than a Ditylium cell is probably unimportant since diatom chains are readily broken up, much more so than the cells of Ditylium which Calanus cannot swallow whole but has to break up, as it does many large diatoms 
(Marshall, I924). If the size of the particles were the only factor in the selection of food by copepods as Fuller and Riley et al. suggest, Harvey's grazing rates suggest that the optimum size of particle is one about the size of a Ditylium cell or a Lauderia chain which would be about the same size and shape, approximately a cylinder 40-50 $\mu$ in diameter and 100-200 $\mu$ long. Chlamydomonas, the food organism used in the experiments described in the present paper, is a solitary flagellate, entirely without projections of any kind, and its linear dimensions are nearly ten times smaller than Ditylium and of the same order as those of Nitzschia. Raymont \& Gross (1942) give its dimensions as $6-8.4 \mu$ by $9.5^{-1} 3.8 \mu$, and a small number of measurements made recently agree closely with those. Yet in the experiments described here Calanus filtered the Chlamydomonas at the same rate as Harvey found with Lauderia, and nearly twenty times as fast as it filtered Nitzschia. It is clear that selection is not merely a matter of size, and some more active mechanism of selection may be involved, but sufficient evidence is not available for further discussion to be profitable.

Fuller \& Clarke (1936) and Fuller (1937) attempted to relate the filtering capacity of Calanus to its food requirements. Fuller \& Clarke computed the volume an individual Calanus would require to filter in Vineyard Sound in July in order to obtain its minimum food requirements as $72 \mathrm{ml}$. per day. From a different estimate of the available food, Fuller calculated that a single Calanus would need a minimum filtering rate of the order of $30 \mathrm{ml}$. per day. If this latter estimate is correct, the filtering rate found in the present experiments is quite adequate. But since the amount of food provided by the phytoplankton at any time and place is still uncertain, and the daily requirements of a copepod are difficult to assess, further attempts to relate filtering rate and food requirements can have little value until more evidence is available.

\section{SUMMARY}

The filtering rate of four species of marine planktonic copepods was measured by estimating the rate at which they consumed cultures of Chlamydomonas.

The filtering rate was independent of the concentration of the food organism and it is concluded that the copepods were acting as filter feeders.

The filtering rates were much greater than those reported by Fuller \& Clarke (I936) and Fuller (1937), but agreed with those reported by Harvey (I937).

Some evidence was obtained that grazing was restricted to some only of the $24 \mathrm{hr}$., most probably to the hours of darkness.

The filtering rates were approximately proportional to the square of the linear dimensions of the copepod.

The purely mechanical selection suggested by Fuller (I937) to account for differences in filtering rates obtained with different species of diatoms cannot account for all the differences which have been observed. 
It is probable that the copepods could obtain sufficient particulate food in the sea by filtering a daily volume of water corresponding to the filtering rates found.

\section{REFERENCES}

Bogorov, B. G., 1934. Seasonal changes in biomass of Calanus finmarchicus in the Plymouth area in 1930. Fourn. Mar. Biol. Assoc., Vol. I9, pp. 585-612.

Crawshay, L. R., I9I5. Notes on experiments in the keeping of plankton animals under artificial conditions. Fourn. Mar. Biol. Assoc., Vol. Io, pp. 555-76.

DAKIN, J. W., I908. Notes on the alimentary canal and food of the Copepoda. Internat. Rev. Hydrobiol. Hydrograph., Bd. I, pp. 772-82.

EsterLy, J. L., I9I6. The feeding habits and food of pelagic copepods and the question of nutrition by organic substances in solution in the water. Univ. Calif. Pbl. Zool., Vol. I6, (No. I4), pp. I7I-84.

Fuller, J. L., I937. Feeding rate of Calanus finmarchicus in relation to environmental conditions. Biol. Bull. Woods Hole, Vol. 72. pp. 233-46.

Fuller, J. L. \& Clarke, G. L., I936. Further experiments on the feeding of Calanus finmarchicus. Biol. Bull. Woods Hole, Vol. 70, pp. 308-20.

Harvey, H. W., 1937. Note on selective feeding by Calanus. Fourn. Mar. Biol. Assoc., Vol. 22, pp. 97-100.

KRoGH, A., I93I. Dissolved substance as food for aquatic organisms. Biol. Rev., Vol. 6, pp. 412-42.

Lebour, M. V., 1922. The food of plankton organisms. Fourn. Mar. Biol. Assoc., Vol. 12, pp. 644-77.

- 1930. The Planktonic Diatoms of Northern Seas. London: The Ray Soc.

LohmanN, H., I908. Untersuchungen zur Feststellung des vollständigen Gehaltes des Meeres an Plankton. Wiss. Merresunters., Abt. Kiel, N.F., Bd. IO, pp. I29-370.

- I909. Ueber die Quellen der Nahrung der Meerestiere und Pütters Untersuchungen Hierüber. Internat. Rev. Hydrobiol. Hydrograph., Bd. 2, pp. IO-30.

- I9I. Ueber das Nannoplankton und die Zentrifugierung kleinster Wasserproben zur Gewinning desselben im lebenden Zustande. Internat. Rev. Hydrobiol. Hydrograph., Bd. 4, pp. I-38.

Lowndes, A. G., I935. The swimming and feeding of certain calanoid copepods. Proc. Zool. Soc. Lond., 1935, pp. 687-7I5.

Marshall, S. M., I924. The food of Calanus finmarchicus during 1923. Fourn. Mar. Biol. Assoc., Vol. I3, pp. 473-9.

Pütrer, A., I907. Die Ernährung der Wassertiere. Zeits. Allg. Physiol., Bd. 7, pp. $283-320$.

- 1909. Die Ernährung der Wassertiere und der Stoffhaushalt der Gewässer. Jena. 1925. Die Ernährung der Copepoden. Arch. Hydrobiol., Bd. 15, pp. 70-II7.

Raymont, J. E. G. \& Gross, F., I942. On the feeding and breeding of Calanus finmarchicus under laboratory conditions. Proc. R. Soc. Edin. B, Vol. 6I, pp. 26787.

Riley, G. A., Stommel, H. \& Bumpus, D. F., I949. Quantitative ecology of the plankton of the western North Atlantic. Bull. Bingham Oceanog. Coll., Vol. I2, Art. 3,169 pp.

Wilson, D. P., 1946. The triradiate and other forms of Nitzschia closterium (Ehrenberg) Wm. Smith, forma minutissima of Allen and Nelson. Fourn. Mar. Biol. Assoc., Vol. 26, pp 235-70. 